\title{
Spotlight
}

\section{The Relentless and logjam Success of Imran Khan and Challenges for Naya Pakistan}

\author{
Shahid Ullah Khan ${ }^{1}+, *$ Asif $\mathrm{Kamal}^{2}+$, Wasim Ullah $\mathrm{Khan}^{3} \dagger$ \\ ${ }^{1}$ University of Science and Technology Bannu, KPK, Pakistan. \\ ${ }^{2}$ School of law and political science Ocean University of Qingdao, China. \\ ${ }^{3}$ School of Chemistry and Chemical Engineering, Sun Yet Sen UniversityGuangzhou China \\ ${ }^{2}$ Universtiy of economics and management, City, Countyr. \\ ${ }^{3}$ School of Economics and Management Science, Xxxxx University, City, Country. \\ *Correspondence: shahidbiochem@webmail.hzau.edu.cn
}



A study about Imran Khan (Current Prime minister of Pakistan) and his true struggle toward Naya Pakistan \& encountered the bit of challenges out of many.

Keywords: Imran Khan, Prime minister, Pakistan, Naya Pakistan,

\section{Introduction}

I don't know how to praise Imran Khan, but at least I have just a single line to define him "IMRAN KHAN Is a Person Born to Defeat Hurdles."According to" Khan's long-time teammate Javed Miandad, "Honesty is the one word which sums up Imran Khan's whole life" $[1,2]$. The journey of his politics is started since 1996 while people poke fun at him fun by stating; you Can Play Cricket, Politics Is Not Your Job. Since long he was a cricketer, and he won the world cup for Pakistan in 1992 and has no strong political background which is necessary for Pakistani mafia politics. Despite people's perceptions and illusions, he never gave up and struggling till date. He confronted many hurdles in his political career and came across many bitter statements based on misperceptions of the people even some corrupt and mafia politician risked his personal life ${ }^{[3,4]}$.

I will not go to his history because his history is too long and full of ebbs and flows. But will quote that, his top priority was too aware of the common populace of Pakistan including youth and women that he did and proved by time recently. He believes that without political and social awareness, no nation can succeed. He is a man who challenged the status-quo, who raised political consciousness in the masses from youth to old and women, who worked day and night ceaselessly with great zeal and courage for this nation. He, not only pointed out the greatest menace of Pakistan CORRUPTION but proved to be a man of action rather than words. He pointed out wrong, highlighted the truth and stood by his beliefs firmly.

He organized protests, sit-ins and dragged the sitting Prime Minister Nawaz Sharif to court and then to Adyala jail (famous prison) ${ }^{[11]}$. It is due to his vision, belief and hard works that the politicians and locals stood by his side. The 126 days protest in the capital city Islamabad against rigging in 2013 election become history in the world.

\section{Victory in 2018 General Election}

By the force of his skills and personality, the charismatic Imran Khan endured in the toughest job in Pakistan for a decade. On 25 July when his party Pakistan Tehrik-e-Insaf (PTI) wins majority seats of national assembly and able to make government in center, Imran Khan appeared on TV on 26 July and started his speech by remembering Baluchistan and all those who sacrificed their lives in the G.E'18 and also thanking the nation for placing their trust to him ${ }^{[5,6]}$.

He added that he was ready to investigate allegations of rigging in the polls and also said that there was "no political victimization" in the acrimonious contest. About foreign policy and relation with neighbor countries, Imran Khan commented that we will improve ties with India to resolve Kashmir dispute and also a good relationship with the US by 
equality. While commenting on Afghanistan, he said that "Afghans have suffered most in the "war on terror" ${ }^{[3]}$. Khan has promised to make Pakistan great and peaceful for the next generations. It is hoped that Imran Khan will fulfill his promises and make Pakistan politically stable, economically prosperous and a culturally confident nation. The nation awaits his pledges to be delivered ${ }^{[7,8,9]}$.

\section{Challenges for Imran Khan Government}

As PTI leads in Pakistan's controversial general election 2018 and being a majority party in the National Assembly, form the national government, but unsurprisingly, the government faces multifaceted problems of the country. However, the challenges for the government, in the first place, the government will face knockout the economic crisis. Pakistan's external deficit is augmenting, its foreign exchange reserves petering-out and the value of its currency is depreciating ${ }^{[4]}$.

Imran Khan would have to deal with some nerve-wracking challenges about foreign policy. Efforts will be needed to bring India on the table to negotiate some relief for savagelyoppressed Kashmiris, and for water crisis between the countries. The new government of Pakistan also needs to ensure China stays committed to its planned $\$ 65 \mathrm{bn}$ speculation in China Pakistan Economic Corridor (CPEC) that is anticipated to build direly-required infrastructure for Pakistan and for that reason ImranKhan is visiting Beijing on 6 November ${ }^{[5,11,12]}$.

Dealing with indefinitely numerous challenges confronting the state-pertaining tothe economy, water crisis, energy crisis, foreign policy, internal and border security, and civilmilitary relation- is genuinely a laudable deal. Khan will have to perform exceptionally to consummate his promises of eradicating poverty, opening 10 million jobs, depoliticizing police, autonomous foreign policy, and accountability for all. The PTI led government is facing critical economic challenges after coming into power. According to (Article) the Pakistan foreign exchange reserves are less than $\$ 9$ billion which are not even enough for to cover import for two months. Similarly the current account deficit is $\$ 18$ billion and $\$ 37.6$ billion trade deficit with $\$ 60.8$ billion imports and $\$ 23.2$ billion exports ${ }^{[13,14]}$.

Industry could boast of enjoying rapid technological change, new innovations and the economies of large-scale production. Agriculture has remained as a leading sector for growth and development. The PTI led government rightly recognizes this but; again, this transformation must not rely on the crutches of unaffordable subsidies. A sustainable agro production and labor-absorbing growth in agriculture sector is required. Adaptation of an active-support policy for small farmers be bolstered by replace the existing arrangements.

While promoting incentives to multinational companies, there is need of strengthening the indigenous industry. Reforms in FBR can lead us to generate revenue at a maximum level.

\section{Conclusion}

How to strengthen rupee conditions in contrast to dollars, for this, the current government had already taken steps like, to resume export industry. They provided energy,i.e. gas and electricity on cheap rates and taxes, which will be ensured and implemented soon after the 2018-2019 annual budget. It will help to stabilize industrialization to effectively boost the economic development of Pakistan. Another thing is, How to pay circular debits! For this reason, Imran Khan visited Saudi Arabia, in his visit, Saudi Arab government had decided to keep 3 billion dollars in Pakistan banks to maintain the reserves and also offered 3 billion worth oil purchase on charitable terms to facilitate the government overcome the current oil prices and energy crisis in the country.

In coming days November 2018 Imran Khan will visit China and later Malaysia, it is hoped that both China and Malaysia will help in this regard. But if our export industry gets stronger than the government can be able to earn more dollars to maintain its reserves. A bitter reality is corruption, nepotism, and lack of good governance that make country's top institutions burden on the state because them in institution like PIA, railway, and energy sectors arein debits almost in hundred billion. These sectors have no money to reduce their debits, they all are in loss. The government should initiate three-pronged policy i.e. dialogue, development, and deterrence. Let us hope that our soil will be freed from the terrorism and there will be no more bloodshed in the days to come.

\section{Suggestion and recommendation}

Properly utilize resources.

Focus on renewable source of energy.

Construction of micro level dams.

Political government to be continued.

Use religious school of thought regarding this issue like the Afghan war with Russia.

Make good relationships with neighbor countries.

Make reforms in industry regulations to bring about an "Economic Revolution."

Control on money laundering and use of black money.

\section{Author s Biography}

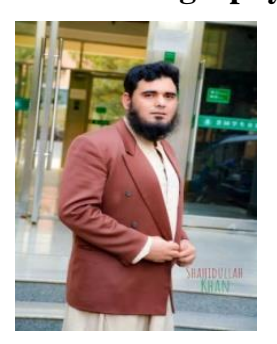

Mr. Shahid Ullah Khan earned his MSc degree (2009) and MPhil degree (2013) in Chemistry from the Department of Chemistry of GPG College Bannu and Kohat University of Science and Technology Kohat KPK Pakistan, respectively. He was awarded as distinguish in both degrees. He is a research scholar presently pursuing his Ph.D. degree in Plant Breeding and Genetics at HZAU, Wuhan, China. He has about 30 publications in a well reputed high impact international journal and 4 books. SU.Khan 
serves as an editorialboard member as well as a reviewer of few journals. Apart from that, he has received best teacher award, best presentation award in Pakistan and research contribution award in China. SU. Khan current research focuses on Genome-Wide Association Studies (GWAS) in Rapeseed.



Mr.Asif Kamal earned his Bachelor of studies in political science from University of Science and Technology Bannu KPK, Pakistan in 2015. He is doing his MS in Environmental and natural resources protection law, school of law and political science Ocean University of China Qingdao PRC. His thesis research is "Billion Tree Tsunami Afforestation Project (BTTP)" in Khyber Pakhtunkhwa.

Wasim Ullah Khan belongs to Bannu,

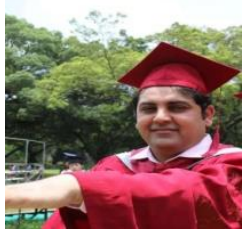
KPK, Pakistan. He received BS from University of Science and Technology Bannu, MS from Gomal university, KPK, Pakistan and PhD degree from Sun Yat Sen university, Guangzhou, Guangdong, China in 2010, 2013 and 2017 respectively. He came back to China in 2017, and since then has been working as a postdoctoral researcher in Sen Yat Sen. His research interests include bulk and nanostructural luminesent materials and multifuctional composite materials togather with their apllication in emission display, peroskite and white LEDs.

References

[1]. WAQAR MASOOD KHAN, Economic challenges for the new government.https://www.pakistantoday.com.pk/201 8/06/30/economic-challenges-for-the-newgovernment/

[2]. The Associated Press Jul 26, 2018, https://www.firstpost.com/world/pakistan-electionresults-2018-imran-khans-22-year-struggle-inpolitics-gets-high-praise-from-long-time-friendand-cricket-great-javed-miandad-4830221.html

[3]. Sana Jamal, Pakistan new foreign policy targets developing ties with neighbors.https:/gulfnews.com/news/asia/pakistan/ pakistan-s-new-foreign-policy-targets-developingties-with-neighbours-1.2268855

[4]. https://www.bbc.com/news/world-asia-india19844270

[5]. Saima Saeed, challenges for imran khan as PM. https://dailytimes.com.pk/275938/challenges-forimran-khan-as-pm/

[6]. FarwaAamerAugust 02, 2018, imran khan economic challenges. https://thediplomat.com/2018/08/pakistan-imrankhans-economic-challenges/

[7]. https://www.coursehero.com/file/prmbkk/Pakistans -economy-growth-poles-are-situated-along-theIndus-River-the/

[8]. Muhammad Sohaib* and FarazJamil, an Insight of Meat Industry in Pakistan with Special Reference to Halal Meat.

[9]. Economy of Pakistan-challenges and prospectus,https://www.slideshare.net/MAyaPirwan i/economy-of-paksitan-iba-paper

[10]. Imran Khan unveils 11-point reforms programme for 'Naya Pakistan' at Lahore rallyApril 29, 2018, https://www.thenews.com.pk/

[11]. https://www.geo.tv/latest/193233-imran-presentsptis-11-point-agenda-for-upcoming-elections

[12]. Zahidhussain 06/01/2014, can political stability hurt economic growth?

[13]. ArbabTehmas Khan, Impacts of law and order situation on economy. http://www.pakissan.com/english/issues/impacts.of. law.and.order.situation.on.economy.shtml

[14]. CIA Facts Sheets-Pakistan 